\title{
Pengembangan Multimedia Pembelajaran Matematika Berbasis Quantum Learning pada Materi Segiempat dan Segitiga untuk Meningkatkan Kemampuan Komunikasi Matematis
}

\author{
Nur Zaharah ${ }^{1}$, Jefri Marzal ${ }^{2}$, M. Haris Effendi $\mathrm{Hsb}^{3}$ \\ ${ }^{1,2}$ Program Studi Magister Pendidikan Matematika, Fakultas keguruan dan Ilmu Pendidikan, Universitas Jambi \\ ${ }^{3}$ Program Studi Magister Pendidikan Kimia, Fakultas keguruan dan Ilmu Pendidikan, Universitas Jambi \\ Jl. Raden Mattaher No.16-Jambi, Kota Jambi, Indonesia \\ nurzaharah909@gmail.com
}

\begin{abstract}
This study aims to describe (1) the process and product development of multimedia learning mathematics based on quantum learning, (2) the validity of multimedia learning mathematics, (3) the practicality of multimedia learning mathematics and (4) the effectiveness of multimedia learning mathematics. This study uses the Research and Development method $(\mathrm{R} \& \mathrm{D})$ which is used to produce certain products, namely based mathematics learning multimedia quantum learning. The development model used in this study is the ADDIE model. Multimedia learning mathematics will be used by seventh grade Al-Falah Islamic Junior High School Jambi. The research subjects were 29 students of class VII.5. In this development research, expert validation states that multimedia has been valid and deserves to be tested. Teachers and students gave positive responses and stated that the multimedia was practical and worth testing. The results of the study obtained an increase in students' mathematical communication skills in the medium category, namely based on the $\mathrm{N}$-Gain Test, it was seen that the score obtained was 0.51 on the medium criteria and based on $t$ test dependent (Paired Sample t Test) a significance value (2-tailed) was obtained. $0.000<0.05$ means that there is a significant difference in students' mathematical communication skills before and after using-based mathematics learning multimedia quantum learning. It can be concluded that the developed mathematics learning multimedia is good and can improve students' mathematical communication skills. Therefore, the developed multimedia can be used by teachers in the learning process on quadrilateral and triangle material to improve mathematical communication skills.
\end{abstract}

Keywords: Multimedia, Quantum Learning, Mathematical Communication

\begin{abstract}
Abstrak
Penelitian ini bertujuan untuk mendeskripsikan (1) proses dan hasil produk pengembangan multimedia pembelajaran matematika berbasis quantum learning, (2) kevalidan multimedia pembelajaran matematika, (3) kepraktisan multimedia pembelajaran matematika dan (4) efektivitas multimedia pembelajaran matematika. Penelitian ini menggunakan metode Research and Development (R\&D) yang digunakan untuk menghasilkan produk tertentu yaitu multimedia pembelajaran matematika berbasis quantum learning. Model pengembangan yang digunakan dalam penelitian ini adalah model ADDIE. Multimedia pembelajaran matematika akan digunakan oleh siswa kelas VII SMP Islam Al-Falah Jambi. Subjek penelitian yaitu 29 orang siswa kelas VII.5. Dalam penelitian pengembangan ini validasi ahli menyatakan multimedia telah valid dan layak diuji cobakan. Guru dan siswa memberikan respon positif dan menyatakan bahwa multimedia tersebut praktis dan layak diuji cobakan. Hasil penelitian diperoleh peningkatan kemampuan komunikasi matematis siswa dalam kategori sedang yaitu berdasarkan Uji N-Gain terlihat bahwa skor yang diperoleh adalah 0,51 pada kriteria sedang, dan berdasarkan uji $t$ dependent (Paired Sample $t$ Test) diperoleh nilai signifikansi (2-tailed) sebesar $0.000<0.05$ artinya terdapat perbedaan yang nyata pada kemampuan komunikasi matematis siswa sebelum dan sesudah penggunaan multimedia pembelajaran matematika berbasis quantum learning. Dapat disimpulkan bahwa multimedia pembelajaran matematika yang dikembangkan baik dan dapat meningkatkan kemampuan komunikasi matematis siswa. Oleh karena itu multimedia yang dikembangkan dapat digunakan oleh guru dalam proses pembelajaran pada materi segiempat dan segitiga untuk meningkatkan kemampuan komunikasi matematis.
\end{abstract}

Kata Kunci: Multimedia, quantum learning, komunikasi matematis

Copyright (c) 2021 Nur Zaharah, Jefri Marzal, M. Haris Effendi Hsb

$\triangle$ Corresponding author: Nur Zaharah

Email Address: nurzaharah909@gmail.com (Jl. Raden Mattaher No.16-Jambi, Kota Jambi, Indonesia)

Received 22 June 2021, Accepted 22 August 2021, Published 23 August 2021 


\section{PENDAHULUAN}

Komunikasi adalah suatu cara untuk menyampaikan suatu pesan dari pembawa pesan ke penerima pesan untuk memberitahu baik secara langsung melalui lisan maupun tidak langsung melalui media (Wijayanto et al., 2018, p. 97). Lebih lanjut lagi, (Yuniarti, 2014) mengungkapkan bahwa komunikasi ialah proses menuangkan pikiran ataupun gagasan serta pemahaman matematis dengan menggunakan angka, gambar serta kata pada komunitas termasuk didalamnya guru, teman sebaya, kelompok, atau kelas. Adapun kemampuan komunikasi matematis adalah kemampuan menyampaikan gagasan/pikiran matematis, baik secara lisan ataupun tulisan dan kemampuan memahami dan menerima gagasan/pikiran matematis orang lain secara teliti, kritis, serta evaluatif untuk mempertajam pemahaman (Lestari \& Yudhanegara, 2015, p. 83). Jadi dapat disimpulkan bahwa kemampuan komunikasi adalah kemampuan seseorang untuk menyampaikan suatu pesan berupa ide ataupun gagasan baik langsung secara lisan maupun melaui perantara lainnya seperti media.

Menurut Baroody, 1993 dalam (Ansari, 2018, p. 5) menyebutkan sedikitnya ada dua alasan penting, mengapa komunikasi dalam matematika perlu ditumbuh kembangkan di kalangan siswa. Pertama, mathematics as language, maksudnya matematika tidak lain sekedar alat bantu berpikir ( $a$ tool to aid thinking), alat untuk menciptakan pola, menyelesaikan masalah atau mengambil kesimpulan, namun matematika bisa sebagai suatu alat yang berharga untuk mengkomunikasikan berbagai ide secara jelas, benar, dan teliti. Kedua, mathematics learning as social activity; maksudnya, sebagai kegiatan sosial dalam pembelajaran matematika, matematika juga sebagai alat interaksi antar siswa, dan juga komunikasi antara guru serta siswa.

Dalam proses pembelajaran kemampuan komunikasi matematik belum seluruhnya dikembangkan secara jelas, sementara itu sebagaimana diungkapkan oleh para matematikawan komunikasi matematis merupakan salah satu kompetensi lain yang perlu diupayakan peningkatannya sebagaimana kompetensi lainnya seperti bernalar dan pemecahan masalah (Ansari, 2018, p. 16). Proses pembelajaran di dalam kelas diarahkan kepada kemampuan anak untuk menghafal informasi, otak anak dipaksa untuk mengingat dan menimbun berbagai informasi tanpa dituntut untuk memahami informasi yang diingatnya untuk menghubungkannya dengan kehidupan sehari-hari, sehingga mengakibatkan ketika anak didik lulus dari sekolah, mereka pintar secara teoritis, tetapi mereka miskin aplikasi. Misalnya anak hafal perkalian dan pembagian, akan tetapi mereka bingung berapa harus membayar manakala ia disuruh membeli 2,5 kg telur dimana harga $1 \mathrm{~kg}$ telur Rp. 12.500,00 (Sanjaya, 2012, p. 1).

Hal ini diperkuat berdasarkan hasil wawancara dengan salah satu guru di SMP Islam Al-Falah Jambi yang mengungkapkan bahwa sebagian siswa kurang aktif dan kemampuan komunikasi siswa kurang berkembang, karena dari total keseluruhan siswa di kelas hanya sebagian yang memiliki kemampuan komunikasi dalam kategori baik yaitu dalam memberikan argumentasi yang benar dan jelas tentang soal-soal cerita dan mampu membuat Langkah-langkah dalam menjawab soal berbentuk cerita. Hal ini termasuk dalam salah satu indikator kemampuan komunikasi matematis yaitu menjelaskan ide, situasi, dan relasi matematika, secara lisan dan tulisan dengan benda nyata, gambar, grafik dan ekspresi 
aljabar. Pada saat pembelajaran di kelas hanya beberapa siswa yang aktif mau menanggapi pertanyaan dari guru dan mau bertanya apabila menemui kesulitan ketika mengerjakan soal.

Kemudian berdasarkan pengamatan yang peneliti lakukan terlihat bahwa kemampuan siswa dalam menyelesaikan soal-soal yang berkaitan dengan komunikasi matematis masih rendah. Hal ini ditandai dengan siswa belum mampu memberikan argumentasi yang benar dan jelas tentang soal-soal yang mereka jawab pada soal berbentuk cerita. Keberanian untuk menyampaikan ide-ide dan argumentasi yang benar dan jelas masih kurang pada waktu proses pembelajaran yang ditandai dengan siswa belum mampu untuk membuat langkah-langkah dalam menjawab soal-soal latihan. Kondisi di atas terjadi karena dalam pembelajaran matematika konvensional siswa jarang sekali diminta untuk mengkomunikasikan ide-idenya. Siswa cenderung pasif dalam pembelajaran, dimana siswa lebih banyak mengamati, mencatat dan mendengarkan penjelasan guru, dan kurang lancar saat mempersentasikan jawaban kepada temannya serta mengalami kesulitan saat guru meminta siswa menyimpulkan pembelajaran pada saat itu.

Peneliti juga melakukan wawancara dengan beberapa siswa. Adapun hasil wawancara diketahui bahwa siswa mengalami kesulitan untuk menyelesaikan soal-soal yang berkaitan dengan komunikasi matematis yang diberikan oleh guru. siswa berinisial WRR mengatakan bahwa belajar di kelas rata-rata hanya menghafal, tanpa mengenali dan mengalami langsung materi yang dipelajari. Guru langsung menjelaskan topik yang akan dipelajari, dilanjutkan dengan pemberian contoh soal dan soal untuk latihan. Hal ini membuat siswa apabila ditanya suatu konsep atau proses siswa tidak bisa menjawab dengan penuh keyakinan atau lebih memilih diam.

Pentingnya kemampuan komunikasi matematis, sehingga diharapkan siswa dapat mengembangkan kemampuan tersebut. Namun dalam banyak kasus, siswa sulit dalam mengambangkan kemampuan komunikasi matematis. (Darkasyi et al., 2014) mengungkapkan bahwa kemampuan komunikasi matematis siswa masih rendah disebabkan guru masih cenderung aktif dengan pendekatan ceramah menyampaikan materi kepada peserta didik sehingga siswa dalam komunikasi matematis masih sangat kurang.

Berdasarkan penelitian yang dilakukan oleh (Wijayanto et al., 2018) tentang analisis kemampuan komunikasi matematis siswa SMP pada materi segitiga dan segiempat didapatkan kesimpulan bahwa kemampuan komunikasi matematis siswa SMP pada materi segitiga dan segiempat masih termasuk kategori rendah. Karena dari soal-soal yang diujikan terdapat dua butir soal dari dua indikator kemampuan komunikasi matematis yang masih berada pada skala $\leq 33 \%$ dan siswa kesulitan dalam menyelesaikan soal no 4 dan 5 yang sesuai dengan indikator kemampuan komunikasi matematis yaitu membuat konjektur, menyusun argumen, merumuskan definisi dan generalisasi, serta mengungkapkan kembali suatu aturan paragraf matematika dalam bahasa sendiri masih tergolong rendah. Dari hasil penelitian ini, terlihat bahwa kemampuan komunikasi matematis siswa masih kurang.

Salah satu upaya yang dapat dilakukan untuk menyikapi kurangnya kemampuan komunikasi matematis siswa diantaranya yaitu dengan menggunakan model pembelajaran quantum learning pada 
saat proses pembelajaran berlangsung. Berdasarkan penelitian yang dilakukan oleh (Kusumawati \& Manopo, 2016) diperoleh persentase peningkatan rata-rata keseluruhan aktivitas siswa dari siklus I ke siklus II yaitu pada siklus I sebesar 67,67\% termasuk dalam kualifikasi baik dan pada siklus II sebesar 74,33\% termasuk dalam kualifikasi baik. Dari penelitian tersebut terlihat bahwa model pembelajaran quantum learning dapat meningkatkan kemampuan komunikasi matematis dan aktivitas siswa. Namun, disarankan agar memaksimalkan penggunaan media untuk memenuhi gaya belajar siswa yang berbedabeda dan memperhatikan alokasi waktu yang sudah ditetapkan agar semua dapat terlaksana. Maka dari itu peneliti ingin mengembangkan sebuah media pembelajaran khusus mata pelajaran matematika materi segiempat dan segitiga yang berbentuk multimedia pembelajaran matematika berbasis quantum learning dan dioperasikan pada perangkat komputer.

Menurut (Lestari \& Yudhanegara, 2015, p. 67) Quantum learning merupakan suatu model pembelajaran yang memandang pelaksanaan pembelajaran layaknya permainan musik orkestra-simfoni dimana guru menciptakan suasana kondusif, dinamis, interaktif, partisipasi dan saling menghargai. Adapun dalam pelaksanaanya, model pembelajaran quantum learning menggunakan kerangka pembelajaran tandur. Adapun kerangka belajar menggunakan TANDUR dan maknanya yaitu: (1) Tumbuhkan minat dengan memuaskan, (2) Alami: ciptakan atau datangkan pengalaman umum yang dapat dimengerti semua pelajar, (3) Namai: sediakan kata kunci, konsep, model dan sebuah masukan, (4) Demonstrasikan: memberikan kesempatan bagi pelajar untuk menunjukkan bahwa mereka tahu, (5) Ulangi materi dan menegaskan dan (6) Rayakan: pengakuan untuk penyelesaian, partisipasi, dan pemerolehan keterampilan dan ilmu pengetahuan (Deporter et al., 2014, p. 39). Dengan demikian, belajar menggunakan kerangka tandur bisa membuat guru dan siswa sama-sama aktif.

Seorang guru matematika hendaknya mencari solusi dari situasi pembelajaran matematika yang rumit, susah dimengerti, susah untuk dikomunikasikan serta harus mengikuti perkembnagn IPTEK seperti yang diinginkan oleh siswa. Berkaitan dengan hal tersebut peneliti tertarik untuk mengembangakan multimedia pembelajaran matematika yang interaktif menggunakan Software Adobe Flash Profesional CS6. Menurut (Madcoms, 2012) Adobe Flash Profesional CS6 merupakan salah satu program animasi 3D vektor yang dapat membuat berbagai aplikasi animasi 3D mulai dari kartun, animasi interaktif, persentasi, Video clip, animasi web dan aplikasi animasi lainnya sesuai yang kita butuhkan.

Dari uraian yang telah dikemukakan, peneliti tertarik mengembangkan multimedia pembelajaran matematika. Multimedia pembelajaran matematika yang dimaksud yaitu multimedia pembelajaran yang dikembangkan menggunakan software adobe flash cs6 berbasis quantum learning pada materi segiempat dan segitiga yang bertujuan untuk meningkatkan kemampuan komunikasi matematis siswa. Pada multimedia akan ditampilkan video, gambar, musik dan siswa bisa mengklik maupun mendrag sesuai perintah yang ada pada multimedia yang telah dibuat.

Keterbaruan dari multimedia yang dibuat yaitu multimedia dibuat berbasis quantum learning pada materi segiempat dan segitiga. Hingga saat ini belum ada yang membuat multimedia menggunakan 
software adobe flash cs6 berbasis quantum learning pada materi segiempat dan segitiga. Multimedia dibuat sesuai dengan tahapan quantum learning yaitu tandur (tumbuhkan, alami, namai, demonstrasikan, ulangi dan rayakan).

Pertama, Pada tahap tumbuhkan akan ditampilkan video ataupun gambar yang dapat menstimulus dengan tujuan menumbuhkan minat siswa belajar bangun datar segiempat dan segitiga. Apabila minat siswa untuk mempelajari materi telah muncul, maka materi yang akan dipelajari lebih mudah dipahami. Selanjutnya pada tahap alami menciptakan atau mendatangkan pengalaman umum yang dapat dimengerti oleh semua dengan cara mengklik atau mendrag gambar sesuai perintah yang tersedia sehingga siswa bisa menemukan konsep dan konsep tersebut akan lebih lama diingat. Berikutnya Pada tahap namai disediakan konsep dan rumus untuk memperbaiki apabila ada kesalahan dalam menemukan kosep ataupun rumus pada tahap sebelumnya. Selanjutnya Pada tahap demosntrasikan siswa mendemonstrasikan hasil diskusi kelompok untuk menunjukkan bahwa mereka tahu. Pada tahap ulangi siswa bisa mengulang kembali materi yang telah dipelajari untuk menegaskan bahwa mereka mengingat materi yang telah dipelajari. Terakhir pada tahap rayakan akan diberikan reward atau hadiah sebagai pengakuan terhadap penyelesaian, partisipasi dan pemerolehan ilmu pengetahuan.

\section{METODE}

\section{Jenis dan Desain Penelitian}

Penelitian yang dilaksanakan adalah penelitian dan pengembangan (Research and Development) yang disingkat dengan R\&D. Menurut (Sugiyono, 2017, p. 407) penelitian dan pengembangan adalah penelitian yang digunakan untuk menghasilkan produk tertentu dan menguji keefektifan produk tersebut. Kerangka model pengembangan yang digunakan dalam penelitian ini adalah kerangka model pengembangan ADDIE yang terdiri dari 5 tahapan yaitu analisis, desain, pengembangan, pelaksanaan dan evaluasi (Branch, 2009).

\section{Data Penelitian dan Teknik Pengumulan Data}

Jenis data yang digunakan dalam penelitian ini berupa data kualitatif dan data kuantitatif. Teknik pengumpulan data dalam penelitian ini melalui wawancara, penyebaran angket terbuka, angket tertutup serta tes hasil belajar. Wawancara dilakukan untuk mendapatkan informasi lengkap tentang persepsi siswa maupun guru. Adapun Penyebaran angket dilakukan untuk memperoleh data dari tim validator ahli materi dan ahli desain, guru serta siswa. Selanjutnya tes hasil belajar bertujuan untuk mengukur kemampuan komunikasi matematis siswa yaitu dengan memberikan soal pre-test (tes awal) maupun post-test (tes akhir).

\section{Prosedur Pengembangan}

Pengembangan multimedia berbasis quantum learning yang diterapkan dalam penelitian ini menggunakan kerangka model ADDIE. Adapun Prosedur pengembangan multimedia dapat dilihat pada gambar 1 berikut: 
Pengembangan Multimedia Pembelajaran Matematika Berbasis Quantum Learning Pada Materi Segiempat Dan Segitiga Untuk Meningkatkan Kemampuan Komunikasi Matematis, Nur Zaharah, Jefri Marzal, M. Haris Effendi Hsb

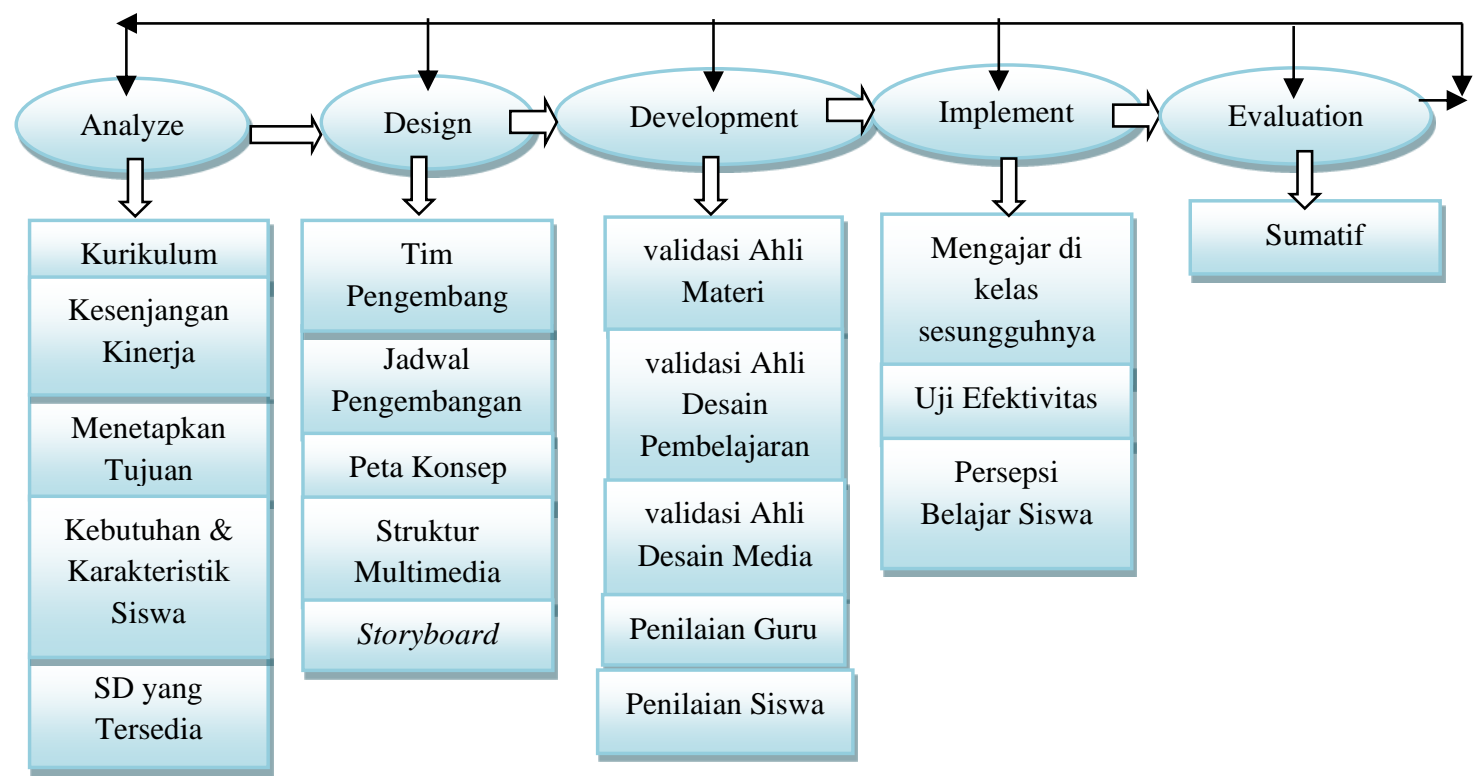

Gambar 1. Prosedur Pengembangan Multimedia

\section{Teknik Analisis Data}

Analisis data dilakukan untuk mengetahui apakah mutimedia yang dikembangkan oleh peneliti sudah memenuhi kriteria valid, praktis dan efektif. Data yang digunakan dalam penelitian ini yaitu kualitatif dan data kuantitatif. Data kualitatif diperoleh dari hasil penyebaran angket yang diberikan kepada ahli materi, ahli desain pembelajaran, ahli desain media, guru dan siswa. Data yang diperoleh dari hasil penyebaran angket dianalisis untuk mengetahui apakah multimedia pembelajaran berbasis quantum learning sudah dikatakan valid atau belum. Adapun data kuantitatif diperoleh dari data hasil belajar yaitu hasil pre-test (tes awal) dan post-test (tes akhir). Data yang didapat dianalisis untuk mengetahui kriteria kepraktisan dan keefektifan dari multimedia yang dikembangkan.

Analisis data peningkatan hasil belajar siswa dapat dihitung menggunakan rumus faktor $\mathrm{g}(\mathrm{N}$ gain) yang dikembangkankan oleh hake (1999) dengan rumus sebagai berikut:

$$
\langle g\rangle=\frac{\left\langle S_{\text {Post }}\right\rangle-\left\langle S_{\text {Pre }}\right\rangle}{\text { skor ideal }-\left\langle S_{\text {Pre }}\right\rangle}
$$

Keterangan:

$\langle g\rangle=$ gain score ternormalisasi

$\left\langle S_{\text {Post }}\right\rangle=$ Skor Post Test

$\left\langle S_{\text {Pre }}\right\rangle=$ Skor Pre Test

Selanjutnya kriteria faktor-g dikategorikan sebagai berikut:

Tabel 1. Kriteria N-gain (Novita et al., 2019)

\begin{tabular}{|c|c|}
\hline$\langle\mathbf{g}\rangle$ & Kriteria \\
\hline $\mathrm{g} \geq 0,70$ & Tinggi \\
\hline $0,30 \leq\langle g\rangle<0,70$ & Sedang \\
\hline$\langle g\rangle<0,30$ & Rendah \\
\hline
\end{tabular}


Multimedia pembelajaran berbasis quantum learning ini dapat dikatakan efektif jika diperoleh hasil belajar yang merupakan peningkatan kemampuan komunikasi matematis dengan batas minimal dalam kategori sedang yang diuji dengan rumus fakor $\mathrm{g}(\mathrm{N}$-gain).

\section{HASIL DAN DISKUSI}

\section{Tahap Analyze (Analisis)}

Tahapan analisis diawali dengan menganalisis kurikulum, memvalidasi kesenjangan kerja, menetapkan tujuan, menganalisis kebutuhan dan karakteristik siswa serta menganalisis sumber daya yang tersedia. Berdasarkan analisis tersebut diperoleh hasil bahwa siswa membutuhkan media pembelajaran yang mampu membuat siswa tertarik selama proses pembelajaran berlangsung sehingga pembelajaran tidak hanya berpusat kepada guru namun dapat mendorong siswa terlibat aktif selama proses pembelajaran.

\section{Tahap Design (Perancangan)}

Pada tahap ini dimulai dengan menentukan tim pengembang, jadwal pengembangan, membuat peta konsep, membuat struktur multimedia dan membuat storyboard. Adapun peta konsep pada tahap design (perancangan) dapat dilihat pada gambar 2 berikut:

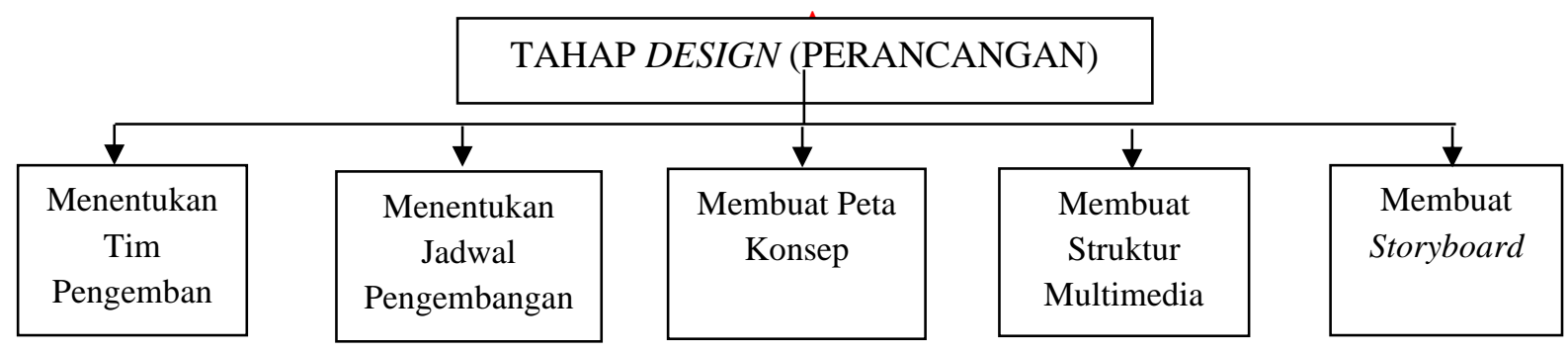

Gambar 2. Peta Konsep Pada Tahap Design

\section{Menentukan Tim Pengembangan}

Dalam mengembangkan multimedia pembelajaran matematika berbasis quantum learning pada materi segiempat dan segitiga untuk meningkatkan kemampuan komunikasi matematis diperlukan tim pengembang yang terdiri dari:

1. Pengembang Multimedia yaitu peneliti sendiri.

2. Pembimbing yaitu Bapak Drs. Jefri Marzal, M.Sc., D.I.T sebagai pembimbing I dan Bapak M. Haris Effendi Hsb, S.Pd, M.Si, Ph.D sebagai pembimbing II.

3. Validator ahli materi yaitu Ibu Dr. Nizlel Huda, M.Kes (salah satu dosen pada Program Studi Magister Pendidikan Matematika).

4. Validator ahli media dan desain pembelajaran yaitu Bapak Dr. Drs. Haryanto, M.Kes (salah satu dosen pada Program Studi Magister Pendidikan Kimia).

5. Guru matematika kelas VII di SMP Islam Al-Falah Jambi yaitu Ibu Novi Madayanti, S.Pd dan siswa kelas VII.2 sebanyak 8 orang siswa 
6. Serta pengguna sebanyak 29 orang siswa kelas VII.5 SMP Islam Al-Falah Jambi

\section{Menyusun Jadwal Pengembangan}

Penelitian pengembangan multimedia pembelajaran matematika berbasis quantum learning pada materi segiempat dan segitiga untuk meningkatkan kemampuan komunikasi matematis diawali dengan tahap analisis yang dilaksanakan pada bulan Mei 2020. Dilanjutkan dengan tahap desain pada bulan Agustus 2020 dan tahap pengembangan pada bulan Februari 2021. Selanjutnya pada bulan Maret 2021 sampai selesai dilaksanakan tahap implementasi dan evaluasi.

\section{Membuat Peta Konsep}

Peta konsep merupakan bagan atau ilustrasi yang menyajkan informasi yang saling terhubung. Adapaun peta konsep pada materi segiempat dan segitiga di kelas VII SMP yang peneliti buat yaitu:

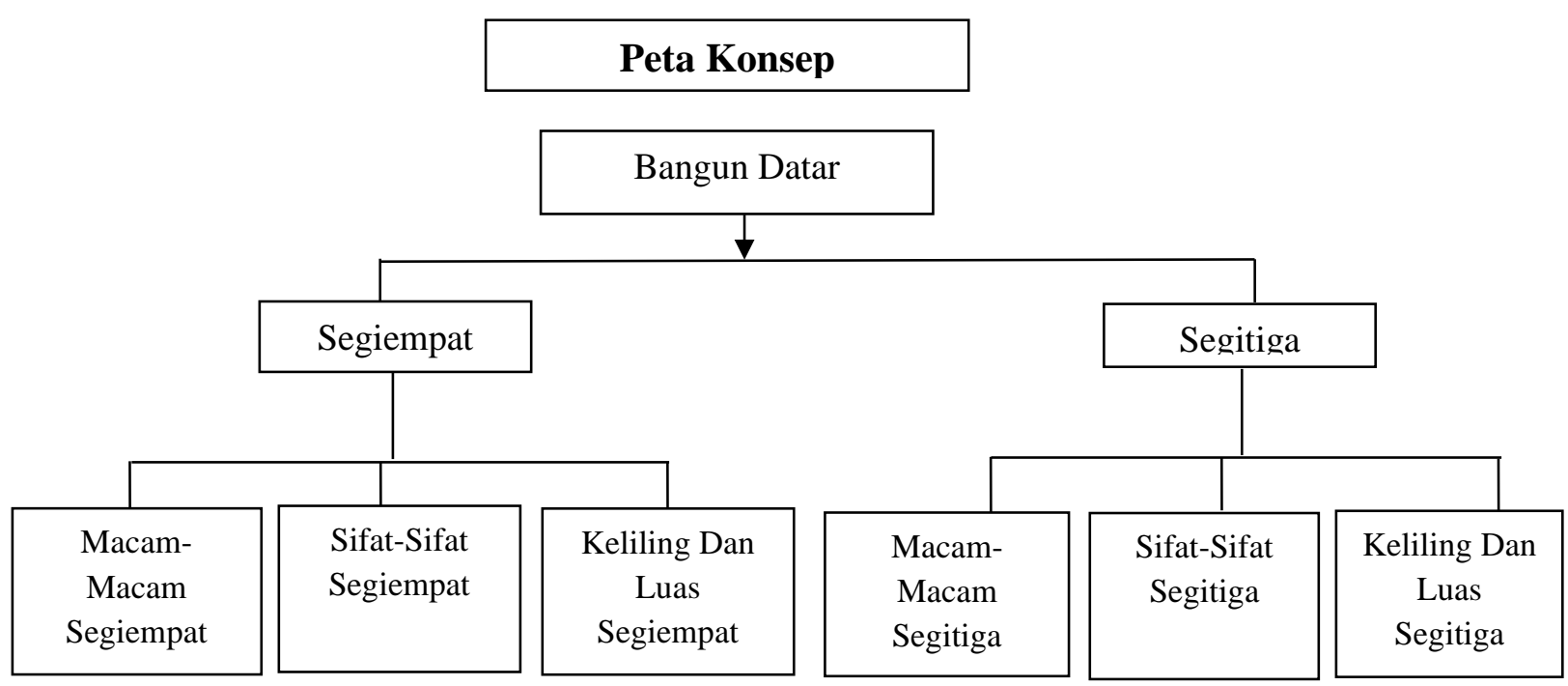

Gambar 3. Peta Konsep Materi Pembelajaran

\section{Struktur Multimedia Pembelajaran Matematika}

Struktur dalam pembuatan suatu media penting dilakukan sebagai gambaran alur navigasi produk yang akan dirancang pada multimedia. Struktur multimedia yang peneliti buat dapat dilihat pada gambar 4.

\section{Story board}

Story board dalam pembuatan suatu media penting dilakukan agar media yang dibuat sesuai dengan yang diharapkan. Tujuan membuat story board yaitu untuk menggambarkan secara rinci letak penataan gambar, animasi, suara, video, serta menu tampilan yang akan ditampilkan pada media. storyboard dapat dilihat pada gambar 5. 


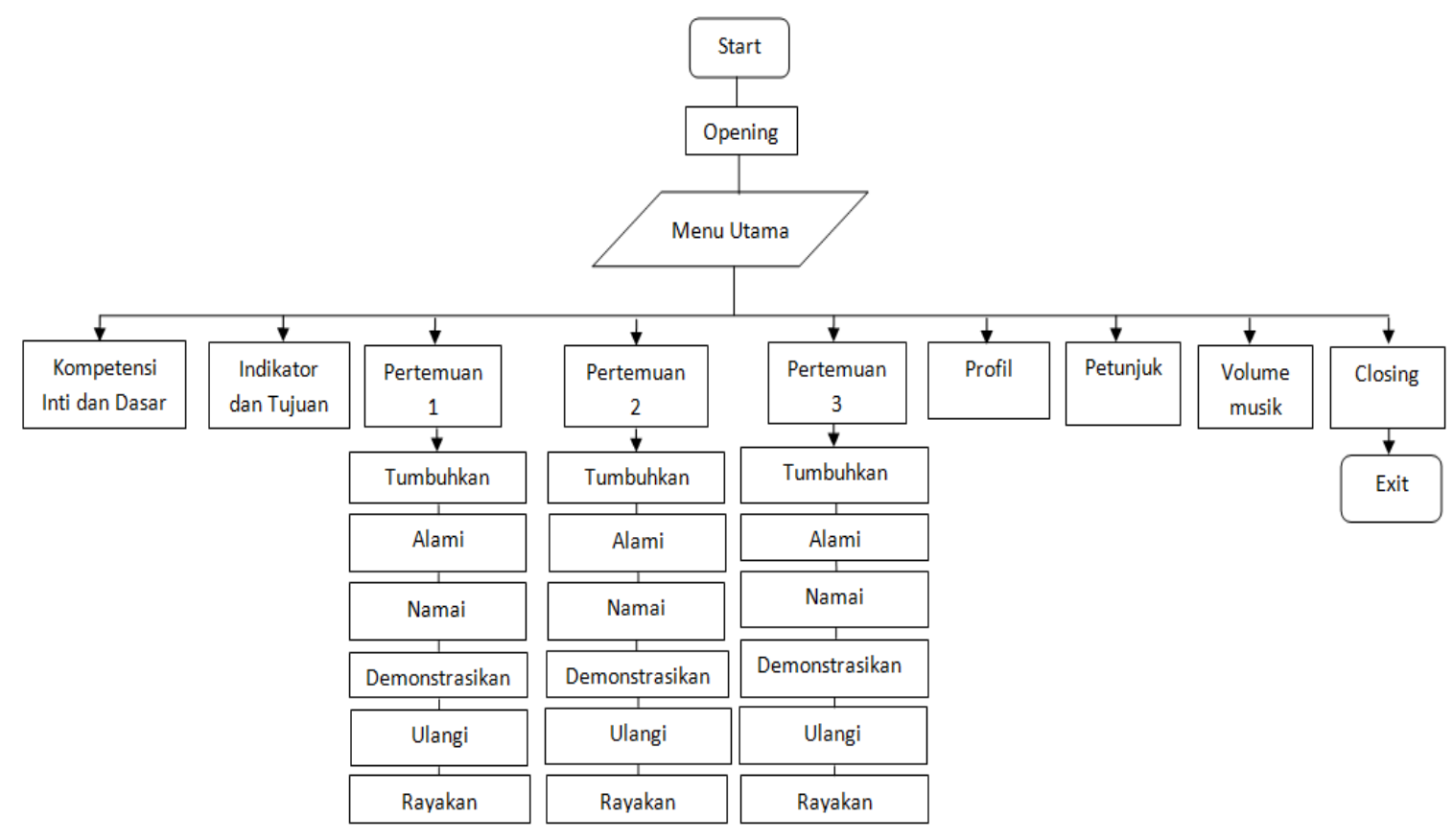

Gambar 4. Struktur Multimedia Pembelajaran

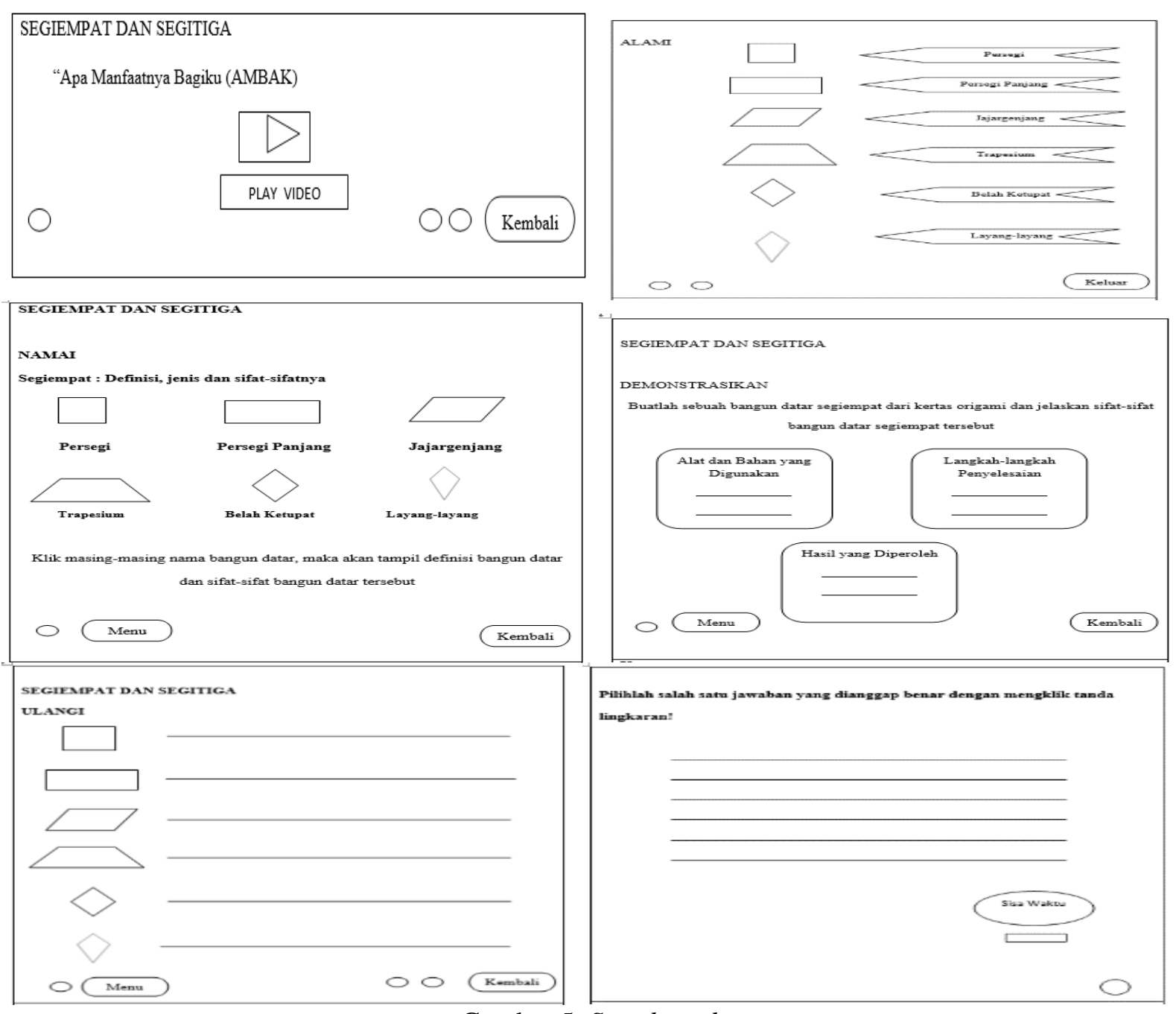

Gambar 5. Storyboard 


\section{Tahap pengembangan (Development)}

Pada tahap ini, peneliti mulai mengembangkan multimedia pembelajaran matemtika berbasis quantum learning pada materi segiempat dan segitiga yang telah dirancang sesuai dengan struktur rancangan yang dirancang pada tahap desain. Multimedia yang telah dirancang divalidasi oleh ahli dibidangnya. Validasi yang dilakukan dalam penelitian ini yaitu validasi oleh ahli materi, validasi ahli desain pembelajaran, validasi ahli desain media, penilain guru matematika dan penilaian siswa.

Berdasarkan validasi oleh ahli materi, ahli desain pembelajaran, ahli desain media, penilaian guru, dan penilaian siswa memberikan komentar positif. Setelah peneliti melakukan revisi sesuai saran dan komentar diperoleh produk multimedia pembelajaran matematika berbasis quantum learning pada materi segiempat dan segitiga yang layak (valid) dan dapat diimplementasikan. Tampilan produk multimedia seperti pada gambar berikut:
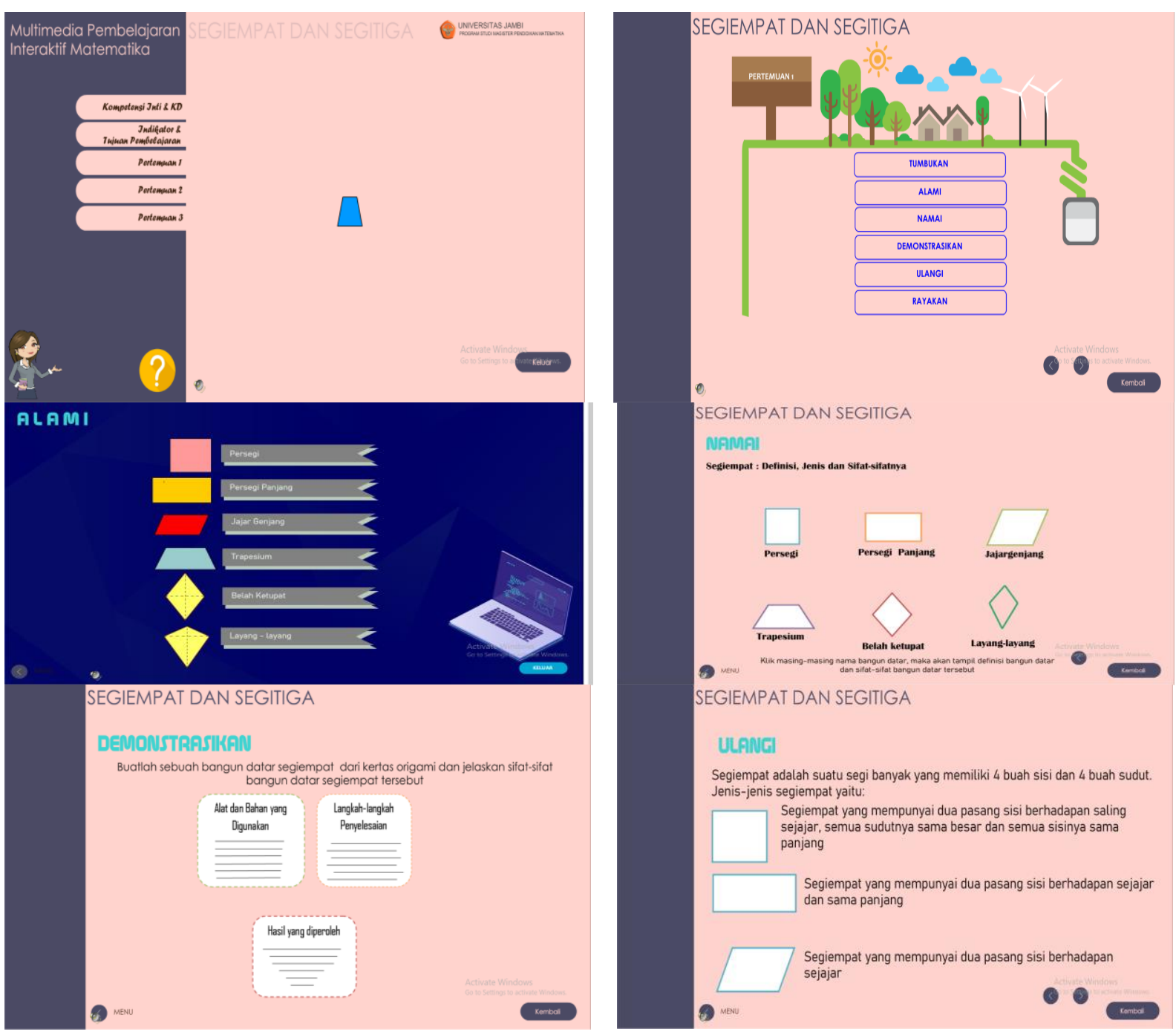

Gambar 6. Tampilan Produk Multimedia Setelah Revisi 


\section{Tahap Implementasi (Pelaksanaan)}

Implementasi dilakukan atau diterapkan dalam situasi kelas yang sebenarnya dengan pengajaran yang sesungguhnya dengan menggunakan multimedia pembelajaran matematika berbasis quantum learning pada materi segiempat dan segitiga yang melibatkan subjek sebanyak 29 siswa atau satu kelas yaitu kelas VII.5 di SMP Islam Al-Falah Jambi.

\section{Hasil Pre-test dan Post-test}

Pre-test dilaksanakan sebelum penggunaan multimedia pembelajaran yang dikembangkan dan post-test dilaksanakan setelah multimedia yang divalidasi diterapkan dalam pembelajaran. Soal yang digunakan pada saat Pre-test dan Post-test berbentuk soal uraian. Soal Pre-test berjumlah dua soal dan soal post-test berjumlah dua soal. Soal disusun berdasarkan ketujuh indikator kemampuan komunikasi matematis. Skor yang diperoleh dari hasil pre-test dan post-test akan diolah dan dianalisis menggunakan uji normalitas, uji t dan uji N-Gain.

Uji normalitas betujuan untuk mengetahui data atau nilai berdistribusi normal atau tidak. Hasil uji normalitas diperoleh bahwa data berdistibusi normal. Selanjutnya, data akan diuji dengan uji t untuk mengetahui apakah terdapat perbedan rata-rata pada dua sampel atau data. Dari hasil uji yang dilakukan diperoleh hasil bahwa terdapat perbedaan yang signifikan antara hasil belajar pada data pretest dan post test. Selanjutnya akan dilakukan uji $\mathrm{N}$-gain untuk mengetahui efektivitas dari penggunaan produk yang telah peneliti buat. Setelah dilakukan uji N-gain, diperoleh nilai N-gain sebesar 0,51 dan dapat diinterpretasikan bahwa terjadi peningkatan dalam kategori sedang.

\section{Tahap Evaluation (Evaluasi)}

Tahap selanjutnya setelah pembelajaran dilaksanakan pada kelas sesungguhnya adalah untuk melihat apakah masih ada kesalahan atau hal-hal yang harus diperbaiki pada produk yang dibuat. Dari evaluasi sumatif ditemukan kesalahan dalam kategori minor yaitu kesalahan penulisan dan pemilihan warna.

\section{Diskusi}

Berdasarkan temuan pada hasil pengembangan yang telah di jelaskan sebelumnya, maka terjawab pertanyaan pertama pada rumusan masalah penelitian yaitu mengenai bagaimana proses dan hasil (produk) multimedia pembelajaran yang dikembankan. Selanjutanya terjawab pertanyaan penelitian menenai kualitas dari produk multimedia pembelajaran yang dikembangkan. Untuk melihat apakah produk berupa multimedia pembelajaran yang telah dibuat memiliki kualitas yang baik maka akan dilihat dari hasil kevalidan produk, kepraktisan produk serta keefektivan produk. Multimedia yang valid, praktis serta efektif dapat dilihat pada gambar 7.

Multimedia berbasis quantum learning sehingga multimedia dibuat sesuai dengan tahapan pada quantum learning yaitu tandur (tumbuhkan, alami, namai, demonstrasikan, ulangi dan rayakan). Dapat dilihat pada gambar 7, pada multimedia dibuat menu sesuai dengan tahapan pada quantum learning yaitu ada menu tumbuhkan, menu alami, menu namai, menu demonstrasikan, menu ulangi dan menu 
rayakan. Sehingga pada penggunaan multimedia tersebut, pengguna dapat mengaskses menu sesuai yang diinginkan dan sesuai dengan tahapan pada quantum leraning.

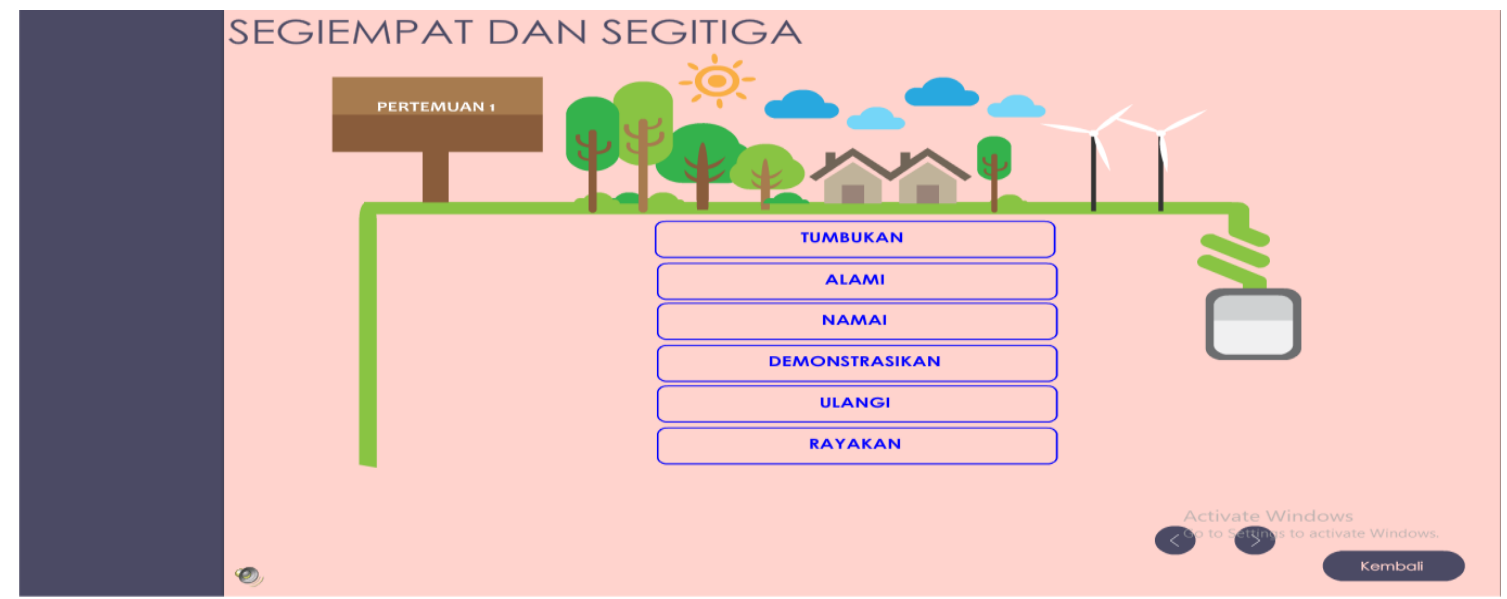

Gambar 7: Tampilan Multimedia Yang Valid, Praktis dan Efektif

\section{Kevalidan Produk}

Kevalidan dapat ditentukan berdasarkan hasil validasi dari masing-masing validator pada ahli bidangnya. Hasil validasi dari ahli materi diperoleh komentar dan saran perbaikan yang telah peneliti perbaiki sehingga materi layak untuk di uji cobakan. Selanjutnya validasi dari ahli desain pembelajaran diperoleh hasil bahwa desain pembelajaran yang diguanakan dalam pembelajaran valid sehingga produk dapat diuji cobakan, hasil validasi ahli media diperoleh hasil bahwa multimedia valid dan layak untuk diuji cobakan setelah perbaikan dan, sedangkan hasil penilaian oleh guru matematika diperoleh hasil yaitu multimedia layak untuk diuji cobakan setelah perbaikan dan juga dikatan valid serta penilaian siswa yang memberikan respon positif terhadap multimedia yang telah dibuat.

Berdasarkan penjelasan dari validasi dan penilaian yang telah dilakukan, oleh karena itu dapat dikatakan bahwa produk berupa multimedia valid dan dapat digunakan pada tahap implmentasi.

\section{Kepraktisan Produk}

Kepraktisan dapat ditentukan berdasarkan hasil penilaian yang dilakukan oleh guru dan siswa. Menurut Nieveen (1999) apabila terdapat kekonsistenan antara kurikulum dengan proses pembelajaran maka perangkat pembelajaran dikatakan praktis jika para responden menyatakan perangkat pembelajaran dapat digunakan dalam pembelajaran yang ditunjukan oleh angket atau kuisioner (apresiasi) oleh guru dan siswa.

Berdasarkan penilaian atau tanggapan yang diberikan oleh guru dan siswa diperoleh hasil bahwa multimedia pembelajaran matematika yang peneliti buat praktis karena mudah digunakan dalam pembelajaran dan tersusun secara terstruktur dan jelas. Begitu juga dengan pernyataan para siswa yang menyatakan bahwa multimedia pembelajaran matematika yang akan digunakan menarik dan mudah digunakan. Berdasarkan penilaian atau tanggapan tersebut dapat dikatakan bahwa produk berupa multimedia yang dibuat praktis. 


\section{Keefektifan Produk}

Keefektifan media pembelajaran menurut Nieveen (1999) diukur dari hasil belajar siswa setelah belajar menggunakan produk media pembelajaran. Hasil belajar yang diukur dalam penelitian in berupa hasil belajar saat pre-test dan post-test. Berdasarkan hasil penelitian di atas diperoleh nilai $\mathrm{N}$-gain sebesar 0,51 dalam kategori sedang. Dari nilai N-gain tersebut terlihat bahwa ada peningkatan kemampuan komunikasi matematis siswa dari sebelum dan sesudah menggunakan produk berupa multimedia pembelajaran. Dari hasil N-gain tersebut dapat disimpulkan bahwa produk berupa multimedia pembelajaran sudah efektif dalam meningkatkan kemampuan komunikasi matematis siswa.

Peningkatan kemampuan komunikasi matematis ini dikarenakan dalam proses pembelajaran siswa dibimbing untuk melakukan suatu aksi atau kegiatan dengan cara mengalami secara langsung pembelajaran (mengklik maupun mendrag sesuai petunjuk yang sudah ada) dengan sintak quantum learning (tumbuhkan, alami, namai, demonstrasikan, ulangi dan rayakan) sehingga siswa bisa mengkomunikasikan ide-idenya dalam bentuk lisan maupun tulisan. Hal ini sejalan dengan penelitian (Darkasyi et al., 2014) yang menyatakan bahwa pembelajaran dengan pendekatan quantum learning dapat meningkatkan kemampuan komunikasi matematis siswa.

\section{KESIMPULAN}

Berdasarkan hasil penelitian dan pembahasan, maka dapat disimpulkan bahwa: (1) Proses pengembangan multimedia pembelajaran matematika menggunakan model ADDIE dengan tahap analyze (analisis), design (desain), development (pengembangan), implementation (implementasi) dan evaluation (evaluasi) sehingga menghasilkan produk berupa multimedia pembelajaran matematika berbasis quantum learning. (2) Multimedia pembelajaaran matematika berbasis quantum learning dinyatakan valid berdasarkan penilaian dari tim validator yaitu validator materi, validator desain pembelajaran, validator desain media, penilain guru dan penilaian siswa. (3) Multimedia pembelajaaran matematika berbasis quantum learning dinyatakan praktis untuk digunakan dalam pembelajaran berdasarkan penilaian dan tanggapan dari guru dan siswa. (4) Multimedia pembelajaaran matematika berbasis quantum learning dinyatakan efektif untuk meningkatkan kemampuan komunikasi matematis. Keefektifan diperoleh dari hasil pre-test dan post-test yang di uji dengan N-gain diperoleh skor sebesar 0,51 yaitu dalam kategori sedang sehingga multimedia pembelajaran matematika yang dikembangkan sudah efektif untuk meningkatkan kemampuan komunikasi matematis. Berdasarkan hasil kevalidan, kepraktisan dan keefektifan produk menunjukkan bahwa multimedia pembelajaran ini memiliki kualitas yang baik dan dapat digunakan pada saat proses pembelajaran materi segiempat dan segitiga.

Peneliti sangat menyarankan kepada guru maupun siswa untuk bisa menggunakan dan memanfaatkan produk multimedia pembelajaran tersebut dengan menjadikan sebagai media dalam pembelajaran materi segiempat dan segitiga di kelas VII. Selanjutnya peneliti juga menyarankan kepada para peneliti yang ingin mengembangkan multimedia agar bisa mengembangkan multimedia pembelajaran matematika berbasis quantum learning pada pokok bahasan lain dengan menggunakan 
bantuan komputer menggunakan program-program aplikasi komputer ataupun berbasis android untuk menghasilkan multimedia pembelajaran matematika yang lebih baik dan menarik.

\section{UCAPAN TERIMA KASIH}

Alhamdulillahirobbil'alamin. Puji syukur kepada Allah SWT yang telah memberikan kemudahan dan kelancaran dalam menyelesaikan penelitian ini. Tak lupa shalawat beriring salam kepada Nabi Muhammad SAW. Peneliti mengucapkan terimakasih kepada kedua orangtua serta keluarga yang selalu memberikan doa maupun dukungan kepada peneliti. Terimakasih juga peneliti ucapkan kepada pembimbing yang telah banyak membantu dalam penelitian ini sehingga penelitian ini dapat terselesaikan yaitu kepada Bapak Drs. Jefri Marzal, M.Sc., D.I.T. dan Bapak M. Haris Effendi Hsb, S.Pd., M.Si., Ph.D. Selanjutnya terimakasih kepada sahabat-sahabat Magister Pendidikan Matematika Angkatan 2018 yang telah menjadi patner diskusi.

\section{REFERENSI}

Ansari, B. I. (2018). Komunikasi Matematik, Strategi Berfikir Dan Manajemen Belajar Konsep dan Aplikasi. Pena.

Branch, R.M. 2009. Instructional Design: The ADDIE Approach. USE: Springer ScienceBisnis Media, LLC, 223 Spring Street, New York, NY 10013, USA.

Darkasyi, M., Johar, R., \& Ahmad, A. (2014). Peningkatan Kemampuan Komunikasi Matematis dan Motivasi Siswa dengan Pembelajaran Pendekatan Quantum Learning pada Siswa SMP Negeri 5 Lhokseumawe. Jurnal Didaktik Matematika, 1(1), 21-34. https://doi.org/10.24815/dm.v1i1.1336

Deporter, B., Reardon, M., \& Nourie, S. S. (2014). Quantum Teaching: Memperaktekkan Quantum Learning Di Ruang-Ruang Kelas. Kaifa.

Hake, R.R. (1999). Analizying Change/Gain Scores. Unpublished. [Online] URL: http://www. physics Indiana. Edu/ sdi/AnalyzingChange-Gain.pdf.

Kusumawati, E., \& Manopo. (2016). Meningkatkan Kemampuan Komunikasi Matematis Siswa Menggunakan Model Pembelajaran Quantum Pada Materi Garis Dan Sudut Di SMPN 13 Banjarmasin. Journal of Chemical Information and Modeling, 4, 118-125.

Lestari, K. E., \& Yudhanegara, M. R. (2015). Penelitian Pendidikan Matematika. PT Refika Aditama. Madcoms. (2012). Kumpas Tuntas Adobe Flash Professional CS6. Andi.

Nieveen, N. (1999). Design Approaches and Tools in Education and Training: Prototyping to Rearch Product Quality. Springer-Science+Bussines Media, B.V. https://doi.org/10.1007/978-94-01142557

Novita, L., Sukmanasa, E., \& Pratama, M. Y. (2019). Penggunaan Media Pembelajaran Video terhadap Hasil Belajar Siswa SD. Indonesian Journal of Primary Education Penggunaan, 3(2), 64-72. http://ejournal.upi.edu/index.php/IJPE/index

Sanjaya, W. (2012). Strategi Pembelajaran Berorientasi Standar Proses Pendidikan. Kencana Prenada 
Media Group.

Sugiyono. (2017). Metode Penelitian Pendidikan (Pendekatan Kuantitatif, Kualitatif dan R\&D). Alfabeta.

Wijayanto, A. D., Fajriah, S. N., \& Anita, I. W. (2018). Analisis Kemampuan Komunikasi Matematis Siswa Smp Pada Materi Segitiga Dan Segiempat. Jurnal Cendekia: Jurnal Pendidikan Matematika, 2(1), 97-104. https://doi.org/10.31004/cendekia.v2i1.36

Yuniarti, Y. (2014). Pengembangan Kemampuan Komunikasi Matematis dalam Pembelajaran Matematika di Sekolah Dasar. EduHumaniora| Jurnal Pendidikan Dasar Kampus Cibiru, 6(2), 109-114. https://doi.org/10.17509/eh.v6i2.4575. 